\title{
SORGHUM GRAIN AND STOVER NUTRIENT CONCENTRATIONS AS INFLUENCED BY TILLAGE, CROPPING SYSTEM AND SOIL AMENDMENT
}

\author{
PALE Siébou ${ }^{*}$, MASON Stephen C. ${ }^{2}$, TAONDA Sibiri Jean-Baptiste ${ }^{1}$, SERME Idriss $^{1}$ and SOHORO Adama $^{1}$ \\ ${ }^{1}$ Institute of the Environment and Agricultural Research (INERA), 04 B.P. 8645 Ouagadougou 04, Burkina Faso \\ ${ }^{2}$ University of Nebraska-Lincoln, Department of Agronomy and Horticulture, 279 Plant Science, P.O. Box 830915, \\ Lincoln, NE 68583-0915, USA \\ https://doi.org/10.35410/IJAEB.2021.5637
}

\begin{abstract}
Grain sorghum intercropped with cowpea or sole cropped are common cropping systems in the Sudano-sahelian agroecological zone of Burkina Faso. A two-year experiment was conducted on the influence of tillage and cropping system with soil amendment (CS/SA) on sorghum grain and stover nutrient concentrations. Tillage had no influence on grain nutrient concentrations. Year and cropping with soil amendment slightly influenced the grain $\mathrm{P}, \mathrm{K}$, and $\mathrm{Mg}$ concentrations. Stover $\mathrm{Mg}$ and $\mathrm{S}$ concentrations were influenced by year, tillage, and CS/SA, while other nutrient concentrations were not. Nitrogen $(\mathrm{N}), \mathrm{P}, \mathrm{K}, \mathrm{Mg}$, and $\mathrm{Zn}$ concentrations $(\mathrm{R}=0.22$ to $0.44)$ were positively associated with grain yield, but only $K(R=0.41)$ and $N(-0.22)$ were associated with stover yield. Nutrient concentration of sorghum grain met human nutritional requirements for $\mathrm{N}(2.15 \%), \mathrm{P}(0.34 \%), \mathrm{Mg}(0.28 \%), \mathrm{Zn}(34 \mathrm{ppm})$ and $\mathrm{Fe}(69 \mathrm{ppm})$ but deficient for $\mathrm{K}(0.45 \%), \mathrm{Mn}(23 \mathrm{ppm})$, and $\mathrm{Cu}(6 \mathrm{ppm})$. Sorghum stover nutrient concentrations exceeded requirements for cattle feed except for $\mathrm{N}(1.6 \%), \mathrm{P}(0.23 \%)$, and $\mathrm{Cu}(7 \mathrm{ppm})$. Genetic and management research to increase sorghum grain $\mathrm{K}, \mathrm{Mn}, \mathrm{Cu}$ concentrations, and stover $\mathrm{N}, \mathrm{P}$, and $\mathrm{Cu}$ concentration to meet human and cattle nutritional needs is merited.
\end{abstract}

Keywords: Compost, human and cattle nutrition, intercrop, scarifying, Sudano-sahelian agroecological 1 zone.

\section{INTRODUCTION}

Population growth (World Bank, 2021), soil degradation and climate change (Mason et al., 2015) are forcing farmers to adopt intensive but more sustainable production systems to meet human food and livestock feed needs while maintaining soil quality in West Africa. Grain sorghum [Sorghum bicolor (L) Moench) is the most important crop gown in the Sudano-sahelian agroecological zone of West Africa (FAO, 2021). It is widely produced either by intercropping with cowpea [Vigna unguiculate (L.) Walp] or as a sole crop using a variety of tillage methods and with or without soil amendment application. Sorghum grain and stover yields for this study were published previously, and found that in the Sudano-sahelian agroecological zone in a sandy loam, low organic matter soil that grain and stover yields increased with use of zaï combined with applications of compost and fertilizer (Palé et al., 2020).

In West Africa, sorghum grain is primarily consumed by humans as whole-grain products and nutritional value is influenced by the quantity, concentration, and bioavailability of nutrients (Kruger et al., 2012). Malnutrition in Burkina Faso was found to be related to inadequate food 
Vol. 06, No. 03; 2021

ISSN: $2456-8643$

consumption, lack of dietary diversity and the consequent low intake of essential nutrients (Taylor et al., 2012). Literature review indicated that recommended dietary concentrations have been previously published (National Academy of Science, 2019a; 2019b) and average sorghum grain nutrient concentrations have been presented for Mali, Niger, Nigeria, and Tanzania (Wortmann et al., 2018) and South Africa. (Mabelebele et al., 2015). Location and year (Wortmann et al., 2018), genotype (Mabelebele et al., 2015; Kumar et al., 2017; Liboreiro Paiva et al., 2017), water stress (Liboreiro Paiva et al., 2017), and fertilizer application (Kumar et al., 2017) have been shown to influence grain nutrient concentrations. Previous research has indicated that reductions in grain nutrient concentrations are commonly associated with increased cereal yield (Buerkert et al.,1998).

Typical sorghum stover nutrient concentrations have been published for West Africa (Van Duivenbooden,1992) and the United States (Cox and Unruh, 2000). Current nutrient requirements for cattle have been published (Gadberry, 2018), but little research has been published relating stover nutrient concentrations to cattle dietary needs. Literature indicated that sorghum and pearl millet (Pennisetum glaucum (L) R. Br.) stover researches had primarily focused on animal performance, metabolizable energy and stover $\mathrm{N}$ concentration (Bidinger and Blümmel, 2007). Nutrient concentrations of plant tissue can be useful to determine sufficiency of nutrient levels for optimal crop growth and nutritional status. The best sufficiency level data for pearl millet in Sub-Saharan Africa have been estimated in recent study (Wortmann et al., 2019). Results from an investigation to understand the nutrient concentration variations in crop growth indicated sufficiency levels of nutrients in the United States as crop growth progresses with decreases at physiological maturity/harvest, thus showing the relationship between critical concentrations for optimizing growth and producing high yield (Cox and Unruh, 2000).

This manuscript addresses the influence of tillage method, cropping system with soil amendment, and year on sole and sorghum intercropped with cowpea on grain and stover nutrient concentrations, and relates these results to human and cattle nutrition, and growing grain sorghum plant critical nutrient levels.

\section{MATERIALS AND METHODS}

\subsection{Study site}

The experiment was conducted from 2011 to 2014 at the Kamboinsé Agricultural Research Station (12 $28^{\prime}$ '29' N lat; $1^{\circ} 33^{\prime} 5.5^{\prime}$ ' W long) in the Sudano-sahelian agroecological zone of Burkina Faso (Figure 1) with total rainfall of $409 \mathrm{~mm}$ in 2011, $626 \mathrm{~mm}$ in 2012, $433 \mathrm{~mm}$ in 2013, and $542 \mathrm{~mm}$ in 2014 for the growing season months of July to Oct.

The soil in the experiment site was a Little Evolved Hydromorphic Alluvial Soil with sandy loam textured surface horizon and low water holding capacity, surface horizon $\mathrm{pH}$ of 7.4, organic carbon (C) concentration of $2.7 \mathrm{~g} \mathrm{~kg}^{-1}, 0.08 \mathrm{~g} \mathrm{~kg}^{-1} \mathrm{~N}, 1.6 \mathrm{mg} \mathrm{kg}^{-1} \mathrm{P}$ and $105 \mathrm{mg} \mathrm{kg}^{-1} \mathrm{~K}$ (Barro and Ouattara, 2011, personal communication). The fields had been fallowed for 10 years previous to 2011. 
Vol. 06, No. 03; 2021

ISSN: $2456-8643$

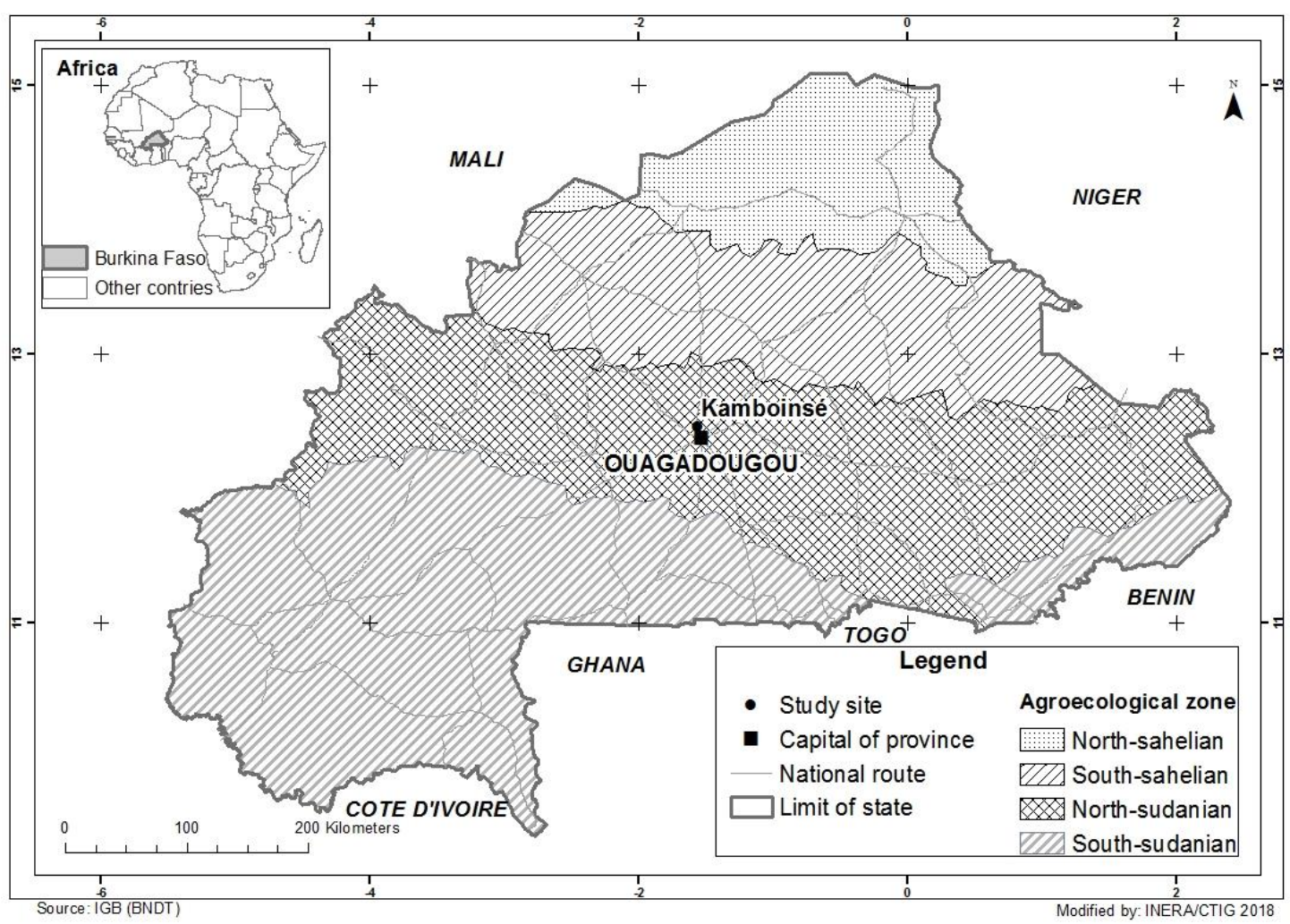

Fig. 1. Map of Burkina Faso showing the Sudano-sahelian agroecological zone and Kamboinsé (study site) [(Source: Geography Institute of Burkina Faso; rivized by the Remote Sensing and Geographical Information Unit (CTIG) at the Institute of Environment and Agricultural Research (INERA), Burkina Faso, 2018)]

\section{2 Experimental design}

A randomized complete block design with a split-plot arrangement of three tillage methods as main plots and eight cropping system with soil amendment treatments allocated in the sub-plots with three replications was used (Table 1). 
Table 1. Tillage methods and soil cropping system with soil amendment treatments for sole intercrop sorghum experiment in Kamboinsé, Burkina Faso, 2012 to 2014.

\begin{tabular}{|c|c|}
\hline Tillage methods & Cropping system with soil amendment (CS/SA) \\
\hline 1. No till & 1. Sole cropped sorghum with no soil amendment applied \\
\hline 2. Scarifying & $\begin{array}{l}\text { 2. Sole cropped sorghum with recommended compost rate of } \\
2500 \mathrm{~kg} \mathrm{ha}^{-1} / \text { year broadcasted in no-zaï-plots at planting. The } \\
2500 \mathrm{~kg} \mathrm{ha}^{-1} \text { were divided equally and applied in each zaï pit at } \\
\text { planting }\end{array}$ \\
\hline \multirow[t]{6}{*}{ 3. Zaï } & $\begin{array}{l}\text { 3. Sole cropped sorghum with recommended mineral fertilizer } \\
\left(\text { so-called fertilizer) at the rate of } 10.5 \mathrm{~kg} \mathrm{~N} \mathrm{ha}^{-1}+17 \mathrm{~kg} \mathrm{P}_{2} \mathrm{O}_{5}\right. \\
\mathrm{ha}^{-1}+10.5 \mathrm{~kg} \mathrm{~K}_{2} \mathrm{O} \mathrm{ha} \mathrm{ha}^{-1} \text { as complete fertilizer broadcasted at } \\
\text { planting or within one week after planting, and } 23 \mathrm{~kg} \mathrm{~N} \mathrm{ha}^{-1} \text { as } \\
\text { urea, applied } 45 \text { days after planting }\end{array}$ \\
\hline & $\begin{array}{l}\text { 4. Sole cropped sorghum with recommended compost and } \\
\text { fertilizers applied }\end{array}$ \\
\hline & $\begin{array}{l}\text { 5. Sorghum intercropped with cowpea and with no soil } \\
\text { amendment }\end{array}$ \\
\hline & $\begin{array}{l}\text { 6. Sorghum intercropped with cowpea and with recommended } \\
\text { compost application at planting }\end{array}$ \\
\hline & $\begin{array}{l}\text { 7. Sorghum intercropped with cowpea and with recommended } \\
\text { fertilizer applications (same rates of NPK complete fertilizer } \\
\text { for both crops, } 23 \mathrm{~kg} \mathrm{~N} \mathrm{ha}^{-1} \text { as urea for grain sorghum at boot } \\
\text { stage, no urea for cowpea) }\end{array}$ \\
\hline & $\begin{array}{l}\text { 8. Sorghum intercropped with cowpea and with recommended } \\
\text { compost and recommended fertilizers applied at planting } \\
\text { (same rates of NPK complete fertilizer for both crops, } 23 \mathrm{~kg} \mathrm{~N} \\
\mathrm{ha}^{-1} \text { as urea for grain sorghum at boot stage, no urea for } \\
\text { cowpea) }\end{array}$ \\
\hline
\end{tabular}

Plots consisted of six rows, 10-m long. Treatments were applied to the same plots each year. Sorghum planting was done at the recommended spacing of $80 \mathrm{~cm}$ between rows and $40 \mathrm{~cm}$ within the row with 1 or 2 plants per hill after thinning. Cowpea planting was done at the recommended density of $80 \mathrm{~cm}$ between rows and $40 \mathrm{~cm}$ within hills in the row, with 1 to 2 plants per hill after thinning. Planting was done alternating two rows of sorghum with two rows of cowpea, giving a total of four rows of sorghum and two rows of cowpea per plot. Sorghum and cowpea were simultaneously planted in July of each year. Weed control was done by hand 
hoeing as needed. The sorghum variety used in the experiment was Sariaso 11 with a maturity rating of 100 to 105 days and intercrop plots planted with the cowpea variety KVX 396-5-2D with a maturity rating of 65 to 70 days.

\subsection{Data collection}

The middle of each sorghum plot was harvested and the harvested area was $25.76 \mathrm{~m}^{2}$. Grain sorghum panicles and stover were hand-harvested, air-dried, threshed (for panicles), weighed, and recorded as dry weight. The experiment was conducted from 2012 through 2014 but nutrient concentrations of grain and stover samples were only collected in 2012 and 2013. Grain and stover sub-samples of sorghum were ground to pass through a 1-mm mesh screen. An automatic combustion method was used for $\mathrm{N}$ digestion and analysis (Miller, 1997), and inductively coupled plasma spectrometry for $\mathrm{P}, \mathrm{K}, \mathrm{Ca}, \mathrm{Mg}, \mathrm{S}, \mathrm{Zn}, \mathrm{Fe}, \mathrm{Mn}$ and $\mathrm{Cu}$ concentrations (Wolf, 2003). Calcium and Fe concentrations were omitted for both grain and stover concentrations due to either a sampling or laboratory error that led to unrealistic values.

\subsection{Data analysis}

Grain and stover nutrient concentrations were analyzed using standard analysis of variance using the General Linear Model Procedure on the software SAS/STAT ${ }^{\circledR}$, version 9.2 (SAS Institute, 2010). Mean separation was done using pair-wise comparisons of significant interaction and main effects. Pearson correlations between grain and stover yields and nutrient concentrations at harvest were conducted. Results were considered significant at $\mathrm{P} \leq 0.05$.

\section{RESULTS}

\subsection{Sorghum grain nutrient concentrations - N, P, K, Mg, S, Zn, Fe, Mn and $\mathrm{Cu}$}

The tillage method or cropping system with soil amendment combinations (CS/SA) had no influence on the $\mathrm{N}(2.15 \%), \mathrm{S}(0.14 \%), \mathrm{Zn}$ (34 ppm), Fe (69 ppm), Mn (23 ppm), and Cu (6 $\mathrm{ppm}$ ) concentrations of the sorghum grain (data not shown). However, the $\mathrm{N}$ concentration of $2.35 \%$ in 2012 was greater than the $1.95 \%$ in 2013.

The tillage method had no influence on sorghum grain concentrations for $\mathrm{P}$ and $\mathrm{Mg}$, however both nutrients were influenced by the year by CS/SA combination interactions. and the grain $\mathrm{K}$ concentration was influenced by the CS/SA main effect (Table 2). Both $\mathrm{P}$ and $\mathrm{Mg}$ grain concentrations were greater in the higher seasonal rainfall and higher grain yield year of 2012 than in the lower grain yield year of 2013. Averaged across years, the sorghum grain P concentrations were 0.06 to $0.07 \%$ higher for sole cropped sorghum with either fertilizer or compost application than for sole cropped sorghum without soil amendment and intercropped sorghum with compost plus fertilizer applied, very similar to results in 2012. In 2013, the grain P concentration for intercropped sorghum with fertilizer applied was 0.08 to $0.12 \%$ higher than for intercropped sorghum with compost and compost plus fertilizer application. Averaged across years, the sorghum grain Mg concentrations were 0.02 to $0.03 \%$ higher for sole cropped sorghum with either compost or fertilizer applied and intercropped sorghum with fertilizer applied than for sole cropped sorghum without soil amendment, and intercropped sorghum with either compost or compost plus fertilizer applied. The sole cropped sorghum grain $\mathrm{Mg}$ without soil amendment was 0.03 to $0.05 \%$ lower than other treatments in 2012, while in 2013, sole cropped sorghum 
with compost and with fertilizer, and intercropped sorghum with fertilizer were 0.03 to $0.05 \%$ higher than for intercropped sorghum with compost and with compost plus fertilizer applications. Averaged across year and tillage methods, the grain $\mathrm{K}$ concentration for sole cropped sorghum with fertilizer applied was 0.04 to $0.06 \%$ higher than sole cropped without soil amendment, and intercropped sorghum with compost and with compost plus fertilizer applications.

Table 2. Year (Y) $x$ Cropping system with soil amendment (CS/SA) effect on sorghum grain nutrient concentrations in Kamboinsé, 2012 through 2013, Burkina Faso. [Analysis of variance probability: $P_{P_{Y} \times C S / S A}=0.03, P_{Y}=0.01, P_{C S / S A}=0.10$; Probability of CS/SA main effect on $\left.\mathrm{K}=0.05 ; \mathrm{Mg}_{\mathrm{P}_{\mathrm{X}} \mathrm{CS} / \mathrm{SA}}=0.04, \mathrm{P}_{\mathrm{Y}}=0.23, \mathrm{P}_{\mathrm{CS} / \mathrm{SA}}=0.02\right]$.

\begin{tabular}{|c|c|c|c|c|c|c|c|}
\hline \multirow{2}{*}{\begin{tabular}{|l} 
Cropping system \\
with soil amendment \\
$(\mathrm{CS} / \mathrm{SA})$
\end{tabular}} & \multicolumn{3}{|c|}{$\begin{array}{c}\text { Phosphorus } \\
(\% \mathrm{P})\end{array}$} & \multirow{2}{*}{$\begin{array}{l}\text { Potassium } \\
(\% \mathrm{~K}) \\
2012-2013\end{array}$} & \multicolumn{3}{|c|}{$\begin{array}{c}\text { Magnesium } \\
(\% \mathrm{Mg})\end{array}$} \\
\hline & 2012 & 2013 & Mean & & 2012 & 2013 & Mean \\
\hline $\begin{array}{l}\text { Sole cropped + without soil } \\
\text { amendment }\end{array}$ & $0.33^{\mathrm{bA}}$ & 0.35 abA & $0.34^{\mathrm{b}}$ & $0.42^{\mathrm{b}}$ & $0.16^{\mathrm{bA}}$ & $0.18 \mathrm{abA}$ & $0.17^{\mathrm{b}}$ \\
\hline Sole cropped + Compost & $0.45^{\mathrm{aA}}$ & $0.36^{\mathrm{abB}}$ & $0.40^{\mathrm{a}}$ & $0.47^{\mathrm{ab}}$ & $0.21^{\mathrm{aA}}$ & $0.19^{\mathrm{aA}}$ & $0.20^{\mathrm{a}}$ \\
\hline Sole cropped + Fertilizer & $0.45^{\mathrm{aA}}$ & $0.36^{\mathrm{abB}}$ & $0.41^{\mathrm{a}}$ & $0.48^{\mathrm{a}}$ & $0.20^{\mathrm{aA}}$ & $0.19^{\mathrm{aA}}$ & $0.19^{\mathrm{a}}$ \\
\hline $\begin{array}{l}\text { Sole cropped }+ \text { Compost }+ \\
\text { Fertilizer }\end{array}$ & $0.41 \mathrm{abA}$ & $0.34^{\mathrm{abA}}$ & $0.37^{\mathrm{ab}}$ & $0.44^{\mathrm{b}}$ & $0.19^{\mathrm{aA}}$ & $0.17^{\mathrm{abA}}$ & $\underset{\mathrm{ab}}{0.18}$ \\
\hline $\begin{array}{l}\text { Intercropped + without soil } \\
\text { amendment }\end{array}$ & $0.45^{\mathrm{aA}}$ & $0.32^{\mathrm{abB}}$ & $0.38^{a b}$ & $0.47^{\mathrm{ab}}$ & $0.21^{\mathrm{aA}}$ & $0.18^{a b B}$ & $0.19^{\mathrm{a}}$ \\
\hline Intercropped + Compost & $0.42^{\mathrm{aA}}$ & $0.29^{\mathrm{bB}}$ & $0.35^{\mathrm{ab}}$ & $0.44^{b}$ & $0.19^{\mathrm{aA}}$ & $0.15^{\mathrm{bB}}$ & $0.17^{\mathrm{b}}$ \\
\hline Intercropped + Fertilizer & $0.39^{\mathrm{abA}}$ & $0.37^{\mathrm{aA}}$ & $0.38^{a b}$ & $0.45^{\mathrm{ab}}$ & $0.19^{\mathrm{aA}}$ & $0.20^{\mathrm{aA}}$ & $0.19^{\mathrm{a}}$ \\
\hline $\begin{array}{l}\text { Intercropped + Compost }+ \\
\text { Fertilizer }\end{array}$ & $0.43^{\mathrm{aA}}$ & $0.25^{\mathrm{bB}}$ & $0.34^{\mathrm{b}}$ & $0.44^{\mathrm{b}}$ & $0.19^{\mathrm{aA}}$ & $0.16^{\mathrm{bB}}$ & $0.17^{\mathrm{b}}$ \\
\hline Mean & $0.41^{\mathrm{A}}$ & $0.33^{\mathrm{B}}$ & & & $0.19^{\mathrm{A}}$ & $0.18^{\mathrm{B}}$ & \\
\hline
\end{tabular}

$\dagger$ Values followed by the same small letter in a column and capital letter in a row are not significantly different at $\mathrm{P}$ $\leq 0.5$. 


\subsection{Sorghum stover nutrient concentrations - N, P, K, Mg, S, Zn, Mn, and $\mathrm{Cu}$}

Stover differences for $\mathrm{P}(0.23 \%), \mathrm{K}(1.13 \%)$, and $\mathrm{Mn}(55 \mathrm{ppm})$ concentrations differences were not found across tillage, and CS/SA combinations in this study (data not presented). However, $\mathrm{P}$ average concentrations of $0.39 \%$ in the higher stover yield of year 2012 were higher than the 0.07\% obtained in the low stover yield year of 2013 (Palé et al., 2020).

Stover differences in $\mathrm{N}, \mathrm{Mg}$, and $\mathrm{Cu}$ concentrations were caused by the Year $\mathrm{x}$ Tillage interaction effect (Table 3). Averaged across years, the stover $\mathrm{N}$ concentrations were similar across tillage methods, but $1.29 \%$ higher in 2013than in 2012. Sorghum produced with the zaï, had 0.16 to $0.24 \%$ higher stover $\mathrm{N}$ concentration than other tillage methods in 2012, but not in 2013.

Table 3. Year ( $(Y) \times$ Tillage method (T) effect on sorghum stover nutrient concentrations in sorghum/cowpea intercropped in Kamboinsé, 2012 through 2013. Burkina Faso [Analysis of variance probability: $\mathrm{NP}_{\mathrm{YXT}}=0.01, \mathrm{P}_{\mathrm{Y}}=0.08, \mathrm{P}_{\mathrm{T}}=0.39 ; \mathrm{Mg} \mathrm{P}_{\mathrm{YxT}}=0.02, \mathrm{P}_{\mathrm{Y}}=0.04, \mathrm{P}_{\mathrm{T}}=$ 0.19; $\left.\mathrm{Cu} \mathrm{P}_{\mathrm{YXT}}=0.05, \mathrm{P}_{\mathrm{Y}}=0.09, \mathrm{P}_{\mathrm{T}}=0.57\right]$.

\begin{tabular}{|c|c|c|c|c|c|c|c|c|c|}
\hline \multirow[b]{2}{*}{ Tillage Method } & \multicolumn{3}{|c|}{ Nitrogen $(\% \mathrm{~N})$} & \multicolumn{3}{|c|}{ Magnesium (\% Mg) } & \multicolumn{3}{|c|}{ Copper (ppm Cu) } \\
\hline & 2012 & 2013 & Mean & 2012 & 2013 & Mean & 2012 & 2013 & Mean \\
\hline No till & $0.88^{\mathrm{bB}}$ & $2.23^{\mathrm{aA}}$ & $1.55^{\mathrm{a}}$ & $0.21^{\mathrm{bA}}$ & $0.18^{\mathrm{aB}}$ & $0.20^{\mathrm{b}}$ & $10^{\mathrm{aA}}$ & $6^{\mathrm{aB}}$ & $8^{\mathrm{a}}$ \\
\hline Scarifying & $0.80^{\mathrm{bB}}$ & $2.22^{\mathrm{aA}}$ & $1.51^{\mathrm{a}}$ & $0.23^{\mathrm{bA}}$ & $0.19^{\mathrm{aB}}$ & $0.21^{\mathrm{b}}$ & $7^{\mathrm{bA}}$ & $6^{\mathrm{aA}}$ & $7^{\mathrm{b}}$ \\
\hline Zaï & $1.044^{\mathrm{aB}}$ & $2.17^{\mathrm{aA}}$ & $1.60^{\mathrm{a}}$ & $0.26^{\mathrm{aA}}$ & $0.19^{\mathrm{aB}}$ & $0.23^{\mathrm{a}}$ & $9^{\mathrm{abA}}$ & $6^{\mathrm{aB}}$ & $7^{\mathrm{ab}}$ \\
\hline Mean & $0.91^{\text {в }}$ & $2.20^{\mathrm{A}}$ & & $0.23^{\mathrm{A}}$ & $0.19^{\mathrm{B}}$ & & $9^{\mathrm{A}}$ & $6^{\mathrm{B}}$ & \\
\hline
\end{tabular}

$\dagger$ Values followed by the same small letter in a column and capital letter in a row are not significantly different at $\mathrm{P}$ $\leq 0.5$.

Stover Mg concentration was $0.04 \%$ higher in 2012 than 2013 (Tables 3 and 4), and stover $\mathrm{Cu}$ concentration was $3 \mathrm{ppm}$ higher (Table 3). In 2012 and averaged across years, the stover $\mathrm{Mg}$ concentrations were highest for use of zaï, with scarifying and no till having the lowest and similar Mg concentrations. In 2012, the sorghum stover $\mathrm{Cu}$ concentration was highest with use of no-till and lowest for scarifying tillage. The tillage method had no effect on $\mathrm{Mg}$ and $\mathrm{Cu}$ concentrations in 2013. 
Table 4. Year (Y) $x$ Cropping system with soil amendment (CS/SA) effect on sorghum stover nutrient concentrations in sorghum/cowpea intercropped in Kamboinsé, 2012 through 2013. Burkina Faso [Analysis of variance probability: $M g P_{Y X C S / S A}=0.01, P_{Y}=$ $0.04, P_{\mathrm{CS} / S A}<0.1 ; \mathrm{S} \mathrm{P}_{\mathrm{YXCS} / \mathrm{SA}}=0.01, \mathrm{P}_{\mathrm{Y}}=0.34, \mathrm{P}_{\mathrm{CS} / \mathrm{SA}}=0.07 ; \mathrm{Zn} \mathrm{P}_{\mathrm{YXCS} / \mathrm{SA}}=0.02, \mathrm{P}_{\mathrm{Y}}=0.84$, $\left.\mathrm{P}_{\mathrm{CS} / \mathrm{SA}}=0.50\right]$.

\begin{tabular}{|c|c|c|c|c|c|c|c|c|c|c|}
\hline \multirow{2}{*}{\multicolumn{2}{|c|}{$\begin{array}{l}\text { Cropping system } \\
\text { with soil } \\
\text { amendment } \\
\text { (CS/SA) }\end{array}$}} & \multicolumn{3}{|c|}{ Magnesium (\% Mg) } & \multicolumn{3}{|c|}{ Sulphur (\% S) } & \multicolumn{3}{|c|}{ Zinc (ppm Zn) } \\
\hline & & 2012 & 2013 & Mean & 2012 & 2013 & Mean & 2012 & 2013 & Mean \\
\hline $\begin{array}{l}\text { Sole cropped } \\
\text { without } \\
\text { amendment }\end{array}$ & $\begin{array}{r}+ \\
\text { soil }\end{array}$ & $0.22^{\mathrm{bcA}}$ & $0.19^{\mathrm{aB}}$ & $0.21^{\mathrm{b}}$ & $0.10^{\mathrm{bB}}$ & $0.15^{\mathrm{aA}}$ & $0.12^{b}$ & $31^{\mathrm{bA}}$ & $37^{\mathrm{aA}}$ & $34^{\mathrm{ab}}$ \\
\hline $\begin{array}{l}\text { Sole cropped } \\
\text { Compost }\end{array}$ & + & $0.24^{\mathrm{bA}}$ & $0.18^{a B}$ & $0.21^{\mathrm{b}}$ & $0.11^{\mathrm{bB}}$ & $0.13^{\mathrm{aA}}$ & $0.12^{b}$ & 37 abA & $39^{\mathrm{aA}}$ & $34^{\mathrm{ab}}$ \\
\hline $\begin{array}{l}\text { Sole cropped } \\
\text { Fertilizer }\end{array}$ & & $0.27^{\mathrm{aA}}$ & $0.19^{\mathrm{aB}}$ & $0.23^{\mathrm{a}}$ & $0.11^{\mathrm{bB}}$ & $0.15^{\mathrm{aA}}$ & $0.13^{b}$ & $30^{\mathrm{bA}}$ & $37^{\mathrm{aA}}$ & $33^{b}$ \\
\hline $\begin{array}{l}\text { Sole cropped } \\
\text { Compost } \\
\text { Fertilizer }\end{array}$ & + & $0.26^{\mathrm{abA}}$ & $0.20^{\mathrm{aB}}$ & $0.23^{\mathrm{a}}$ & $0.11^{\mathrm{bB}}$ & $15^{\mathrm{aA}}$ & $0.13^{b}$ & $32^{\mathrm{bA}}$ & $35^{\mathrm{aA}}$ & $33^{b}$ \\
\hline $\begin{array}{l}\text { Intercropped } \\
\text { without } \\
\text { amendment }\end{array}$ & $\begin{array}{r}+ \\
\text { soil }\end{array}$ & $0.20^{\mathrm{cA}}$ & $0.18^{\mathrm{aA}}$ & $0.19^{b}$ & $0.15^{\mathrm{aA}}$ & $0.14^{\mathrm{aA}}$ & $0.15^{\mathrm{a}}$ & $46^{\mathrm{aA}}$ & $34{ }^{\mathrm{aB}}$ & $40^{\mathrm{a}}$ \\
\hline $\begin{array}{l}\text { Intercropped } \\
\text { Compost }\end{array}$ & + & $0.25 \mathrm{abA}$ & $0.20^{\mathrm{aB}}$ & $0.23^{a b}$ & $0.10^{\mathrm{bB}}$ & $0.15^{\mathrm{aA}}$ & $0.12^{b}$ & $34^{\mathrm{bA}}$ & $36^{\mathrm{aA}}$ & $35^{\mathrm{ab}}$ \\
\hline $\begin{array}{l}\text { Intercropped } \\
\text { Fertilizer }\end{array}$ & + & $0.24^{\mathrm{bA}}$ & $0.18^{\mathrm{aB}}$ & $0.21^{\mathrm{b}}$ & $0.11^{\mathrm{bB}}$ & $0.14^{\mathrm{aA}}$ & $0.12^{b}$ & $36^{\mathrm{bA}}$ & $32^{\text {aA }}$ & $34^{\mathrm{ab}}$ \\
\hline $\begin{array}{l}\text { Intercropped } \\
\text { Compost } \\
\text { Fertilizer }\end{array}$ & $\begin{array}{l}+ \\
+\end{array}$ & $0.19^{\mathrm{cA}}$ & $0.19^{\mathrm{aA}}$ & $0.19^{b}$ & $0.12^{\mathrm{bA}}$ & $0.13^{\mathrm{aA}}$ & $0.13^{b}$ & 39 abA & $32^{\mathrm{aA}}$ & $36^{\mathrm{ab}}$ \\
\hline Mean & & $0.23^{A}$ & $0.19^{\mathrm{B}}$ & & $0.11^{\mathrm{B}}$ & $0.14^{\mathrm{A}}$ & & $36^{\mathrm{A}}$ & $33^{\mathrm{A}}$ & \\
\hline
\end{tabular}

$\dagger$ Values followed by the same small letter in a column and capital letter in a row are not significantly different at $\mathrm{P}$ $\leq 0.5$.

Sorghum stover $\mathrm{Mg}, \mathrm{S}$ and $\mathrm{Zn}$ concentrations were influenced by the year by CS/SA combinations (Table 4). The S concentration was 0.03\% higher in 2013 than in 2012, and there was no difference across years for the $\mathrm{Zn}$ concentration. There were no CS/SA combination differences for $\mathrm{Mg}, \mathrm{S}$ and $\mathrm{Zn}$ in 2013. However, in 2012, the intercropped sorghum with no soil amendment applied stover $\mathrm{Mg}$ concentration was 0.3 to $0.05 \%$ higher than sole cropped, and sole crop sorghum with compost application and intercropped sorghum with compost plus fertilizer application. Sorghum stover $\mathrm{Mg}$ concentration for these treatments were $0.04 \%$ greater than for these treatments than for intercropped sorghum without soil amendment and intercropped sorghum with compost plus fertilizer application. The stover S concentration for intercropped 
sorghum without soil amendment was 0.04 to $0.05 \%$ higher than all other cropping system and soil amendment combinations. The stover $\mathrm{Zn}$ concentration for intercropped sorghum without soil amendment was 0.10 to $0.16 \%$ higher than sole and intercropped sorghum with fertilizer application, intercropped sorghum with compost application, and sole cropped sorghum with compost plus fertilizer application.

Sorghum stover $\mathrm{S}$ and $\mathrm{Mg}$ concentrations were also influenced by the tillage method by cropping system with soil amendment combination interaction (Table 5). Averaged across years and CS/SA combinations, sorghum using the zaï had greater stover Mg concentration than with other tillage methods, while the stover S concentration was similar across years. Averaged across years and tillage methods, the sole cropped sorghum with fertilizer and with compost plus fertilizer and intercropped sorghum with compost application had stover Mg concentrations 0.02 to $0.04 \%$ higher than for other cropping systems and soil amendment applications. However, for no till sorghum had 0.04 to $0.08 \%$ higher stover $\mathrm{Mg}$ concentration for sole crop without soil amendment and with fertilizer application than for intercropped sorghum without soil amendment, with fertilizer, and with compost plus fertilizer applications. Sorghum with scarifying tillage had 0.04 to $0.05 \%$ higher stover Mg concentration for sole cropped sorghum with compost plus fertilizer application and for intercropped sorghum with fertilizer applied. In contrast, with zaï sole cropped sorghum with compost and fertilizer applied and intercropped sorghum with compost application was 0.05 to $0.06 \%$ higher than intercropped sorghum without soil amendment and with compost applied and intercropped sorghum with compost plus fertilizer applied. The stover S concentration was 0.02 to $0.03 \%$ higher for intercropped sorghum without soil amendment than all other cropping system with soil amendment combinations. Sorghum stover S concentrations were similar with scarify and zaï, but for no till, intercropped sorghum without soil amendment was 0.06 to $0.08 \%$ higher than other cropping system with soil amendment combinations. 
Vol. 06, No. 03; 2021

ISSN: $2456-8643$

Table 5. Tillage method (T) $x$ Cropping system with soil amendment (CS/SA) effect on sorghum stover nutrient concentrations in sorghum/cowpea intercropped in Kamboinsé, 2012 through 2013. Burkina Faso [Analysis of variance probability: $M g P_{T x C S / S A}<0.1, P_{T}=$ $\left.0.19, P_{\mathrm{CS} / \mathrm{SA}}<0.1 ; \mathrm{S} \mathrm{P}_{\mathrm{TxCS} / \mathrm{SA}}=0.02, \mathrm{P}_{\mathrm{T}}=0.36, \mathrm{P}_{\mathrm{CS} / \mathrm{SA}}=0.07\right]$.

\begin{tabular}{|c|c|c|c|c|c|c|c|c|}
\hline \multirow{2}{*}{$\begin{array}{l}\text { Cropping system } \\
\text { with soil } \\
\text { amendment } \\
\text { (CS/SA) }\end{array}$} & \multicolumn{4}{|c|}{ Magnesium (\% Mg) } & \multicolumn{4}{|c|}{ Sulphur (\% S) } \\
\hline & No till & Scarifying & Zaï & Mean & No till & Scarifying & Zaï & Mean \\
\hline $\begin{array}{l}\text { Sole cropped + } \\
\text { without soil } \\
\text { amendment }\end{array}$ & $0.23^{\mathrm{aA}}$ & $0.20^{\mathrm{abA}}$ & $0.19^{\mathrm{bA}}$ & $0.21^{\mathrm{b}}$ & $0.13^{\mathrm{bA}}$ & $0.13^{\mathrm{aA}}$ & $0.12^{\mathrm{aA}}$ & $0.12^{b}$ \\
\hline $\begin{array}{l}\text { Sole cropped + } \\
\text { Compost }\end{array}$ & $0.20^{\mathrm{abA}}$ & $0.21 \mathrm{abA}$ & $0.22^{\mathrm{bA}}$ & $0.21^{\mathrm{b}}$ & $0.11^{\mathrm{bA}}$ & $0.12^{\mathrm{aA}}$ & $0.12^{\mathrm{aA}}$ & $0.12^{b}$ \\
\hline $\begin{array}{l}\text { Sole cropped + } \\
\text { Fertilizer }\end{array}$ & $0.24^{\mathrm{aAB}}$ & $0.21^{\mathrm{abB}}$ & $0.25 \mathrm{abA}$ & $0.23^{\mathrm{a}}$ & $0.13^{\mathrm{bA}}$ & $0.12^{\mathrm{aA}}$ & $0.14^{\mathrm{aA}}$ & $0.13^{b}$ \\
\hline $\begin{array}{l}\text { Sole cropped + } \\
\text { Compost + } \\
\text { Fertilizer }\end{array}$ & $0.21^{\mathrm{abB}}$ & $0.23^{\mathrm{aAB}}$ & $0.26^{\mathrm{aA}}$ & $0.23^{\mathrm{a}}$ & $0.13^{\mathrm{bA}}$ & $0.13^{\mathrm{aA}}$ & $0.14^{\mathrm{aA}}$ & $0.13^{\mathrm{b}}$ \\
\hline $\begin{array}{l}\text { Intercropped + } \\
\text { without soil } \\
\text { amendment }\end{array}$ & $0.16^{\mathrm{bB}}$ & $0.24^{\mathrm{aA}}$ & $0.18^{\mathrm{bB}}$ & $0.19^{b}$ & $0.19^{\mathrm{aA}}$ & $0.13^{\mathrm{aB}}$ & $0.12^{\mathrm{aB}}$ & $0.15^{\mathrm{a}}$ \\
\hline $\begin{array}{l}\text { Intercropped + } \\
\text { Compost }\end{array}$ & $0.21^{\mathrm{abB}}$ & $0.20^{\mathrm{abB}}$ & $0.26^{\mathrm{aA}}$ & $0.23^{\mathrm{ab}}$ & $0.13^{\mathrm{bA}}$ & $0.12^{\mathrm{aA}}$ & $0.12^{\mathrm{aA}}$ & $0.12^{b}$ \\
\hline $\begin{array}{l}\text { Intercropped + } \\
\text { Fertilizer }\end{array}$ & $0.19^{\mathrm{bB}}$ & $0.19^{\mathrm{bB}}$ & $0.25^{\mathrm{abA}}$ & $0.21^{\mathrm{b}}$ & $0.12^{\mathrm{bA}}$ & $0.12^{\mathrm{aA}}$ & $0.14^{\mathrm{aA}}$ & $0.12^{b}$ \\
\hline $\begin{array}{l}\text { Intercropped + } \\
\text { Compost + } \\
\text { Fertilizer }\end{array}$ & $0.16^{\mathrm{bB}}$ & $0.20^{\mathrm{abAB}}$ & $0.21^{\mathrm{bA}}$ & $0.19^{b}$ & $0.13^{\mathrm{bA}}$ & $0.13^{\mathrm{aA}}$ & $0.12^{\mathrm{aA}}$ & $0.13^{\mathrm{b}}$ \\
\hline Mean & $0.20^{\mathrm{B}}$ & $0.21^{\mathrm{B}}$ & $0.23^{\mathrm{A}}$ & & $0.13^{\mathrm{A}}$ & $0.12^{\mathrm{A}}$ & $0.13^{\mathrm{A}}$ & \\
\hline
\end{tabular}

$\dagger$ Values followed by the same small letter in a column and capital letter in a row are not significantly different at $\mathrm{P}$ $\leq 0.5$.

\subsection{Correlations between grain and stover yields and nutrient concentrations}

Sorghum grain yield (Palé et al., 2020) was positively associated with $\mathrm{N}(\mathrm{R}=0.35, \mathrm{P} \leq 0.01), \mathrm{P}$ $(\mathrm{R}=0.39, \mathrm{P} \leq 0.01), \mathrm{K}(\mathrm{R}=0.44, \mathrm{P} \leq 0.01), \mathrm{Mg}(\mathrm{R}=0.22, \mathrm{P} \leq 0.05)$, and $\mathrm{Zn}(\mathrm{R}=0.36, \mathrm{P} \leq$ 0.01 ) concentrations while $\mathrm{S}, \mathrm{Ca}, \mathrm{Fe}, \mathrm{Mn}$ and $\mathrm{Cu}$ concentrations were not associated with grain yield. In contrast, sorghum stover yield was only positively associated with stover $\mathrm{K}$ concentration $(R=0.41, P \leq 0.01)$ and negatively associated with $\mathrm{N}$ concentration $(\mathrm{R}=-0.22, \mathrm{P}$ $\leq 0.05$ ) while $\mathrm{P}, \mathrm{S}, \mathrm{Mg}, \mathrm{Zn}, \mathrm{Mn}$ and $\mathrm{Cu}$ concentrations were not associated.

\section{DISCUSSION}

4.1 Sorghum grain nutrient concentrations - N, P, K, Mg, S, Zn, Mn and $\mathrm{Cu}$

Most sorghum grain nutrient levels were not influenced by tillage method and/or CS/SA combinations. Tillage method had no effect on grain $\mathrm{N}, \mathrm{S}, \mathrm{Zn}, \mathrm{Fe}, \mathrm{Mn}$, and $\mathrm{Cu}$ concentrations. 
For sole cropped sorghum, soil amendment application generally increased the grain $\mathrm{P}$ concentration but not for intercropped sorghum. Grain $\mathrm{Mg}$ and $\mathrm{K}$ concentration differences were declared significant, but differences were quite small and of little practical importance. It was concluded that tillage, and cropping system and soil amendment combinations had only minor effect on sorghum grain concentrations. Unexpectedly, several nutrients had positive correlations with grain yield indicating increased sorghum grain yield rather than dilute nutrient concentrations in this study, in contrast to previous results reported by Buerkert et al. (1998).

Assuming that bioavailability was not an issue (Kruger et al., 2012), the grain nutrient concentrations were adequate for 31 to 50 -year-old males weighing $60 \mathrm{~kg}$ and non-pregnant females weighing $40 \mathrm{~kg}$ for $\mathrm{N}, \mathrm{P}, \mathrm{Mg}, \mathrm{Zn}$ and $\mathrm{Fe}$, but deficient for $\mathrm{K}, \mathrm{Mn}$ and $\mathrm{Cu}$ (National Academy of Science, 2019a; 2019b).Improvement of deficient nutrients through genetic improvement (Mabelebele et al., 2015; Kumar et al., 2017; Liboreiro Paiva et al., 2017) and/or targeted fertilizer application (Mabelebele et al., 2015;Bidinger and Blümmel, 2007) to improve sorghum grain nutrient concentrations or supplement diets with diverse foodstuffs, or use biofortified grain (Taylor et al., 2012) are likely needed to meet human dietary needs.

Grain $\mathrm{N}, \mathrm{Mg}$, and $\mathrm{S}$ concentrations were similar to values reported in previous studies (Mabelebele et al., 2015; Liboreiro Paiva et al., 2017; Wortmann et al., 2018).Grain concentration for $\mathrm{Zn}$ and $\mathrm{Cu}$ were similar to findings reported in past researches (Mabelebele et al., 2015), but higher than values reported by other researchers (Mabelebele et al., 2015; Liboreiro Paiva et al., 2017). Sorghum grain concentrations for P, K, Mn, and $\mathrm{Cu}$ were found to be similar to values reported in past researches (Mabelebele et al., 2015; Liboreiro Paiva et al., 2017), but $\mathrm{P}$ and $\mathrm{K}$ were lower, and $\mathrm{Fe}$ and $\mathrm{Mn}$ were much lower than values found in recent study (Wortmann et al., 2018). Sorghum grain nutrient concentrations in this study and in reference citations indicated great variability worldwide.

\subsection{Sorghum stover nutrient concentrations - N, P, K, Mg, S, Zn, Mn, and Cu}

Tillage method influence on sorghum stover nutrient concentration was not uniform across years, but the zaï system did decrease sorghum stover $\mathrm{N}$ and increase $\mathrm{Mg}$ concentrations in the higher seasonal rainfall and higher grain yield year (Palé et al., 2020). Year x CS/SA interaction differences were declared significant for stover $\mathrm{S}$ and $\mathrm{Mg}$ concentrations, but differences were quite small. Stover Zn concentration differences due to year x CS/SA interaction were much greater than for $\mathrm{S}$ and $\mathrm{Mg}$, but inconsistent across year and cropping system with soil amendment applications with no logical best cropping system or soil amendment. In contrast to grain nutrient concentrations, stover grain concentrations were largely not associated with stover yield.

Sorghum nutrient concentrations for feeding cattle were found to be adequate for $\mathrm{Mg}, \mathrm{K}, \mathrm{S}, \mathrm{Zn}$ and $\mathrm{Mn}$ in most cases but low for $\mathrm{Cu}$ (Gadberry, 2018). Stover concentrations for $\mathrm{N}$ and $\mathrm{P}$ were inadequate in 2012 but adequate in 2013. These results indicate the need in some years to apply fertilizer to raise $\mathrm{N}, \mathrm{P}$ and $\mathrm{Cu}$ concentrations in sorghum stover, or supplement cattle rations with $\mathrm{Cu}$ sources to meet cattle nutrient requirements, and $\mathrm{N}$ and $\mathrm{P}$ in certain years. In a similar study with pearl millet produced in the Sahelian agroecological zone of Burkina Faso, the need for either fertilizer to increase $\mathrm{N}$ and $\mathrm{P}$ concentrations of pearl millet stover or supplementation of ration was found necessary to meet cattle $\mathrm{N}$ and $\mathrm{P}$ needs (Palé et al., 2021). 
The stover $\mathrm{P}, \mathrm{Mg}, \mathrm{S}, \mathrm{Zn}, \mathrm{Fe}, \mathrm{Mn}$, and $\mathrm{Cu}$ concentrations at physiological maturity were adequate to meet the critical levels for growth of grain sorghum under the production situation present in this study (Wortmann et al., 2019; Cox and Unruh, 2000). The results suggest that $\mathrm{N}$ concentrations may have been lower than the critical level for optimum plant growth, but the stover sample at physiological maturity was different than the upper-most leaves during reproductive growth that are commonly used to determine critical levels.

Previous studies had shown sorghum stover concentrations for $\mathrm{N}$, and $\mathrm{Cu}$ to be similar to those reported in the present experiment (Youngquist, 1990; Van Duivenbooden, 1992; Maw, 2020). Previous results indicated that stover K concentrations were similar to those in the present study and other recent findings (Maw, 2020), but lower than values observed in some other studies (Youngquist, 1990; Van Duivenbooden, 1992). Stover concentrations for $\mathrm{Zn}$ and Mn were lower than those reported in some past researches (Youngquist, 1990) but higher in others (Maw, 2020). In contrast, the stover $S$ concentration was shown to be similar to past value reported in the literature (Youngquist, 1990), but lower in some other studies (Maw, 2020). Stover nutrient concentrations varied widely across this study and in references cited.

\section{CONCLUSION}

Sorghum grain and stover nutrient concentrations were measured at physiological maturity to assess the influence of tillage, and CS/SA combinations on sorghum grain and stover nutrient concentrations, and on suitability for human food, livestock feed, and nutritional adequacy for yield produced. The CS/SA combinations had no influence on grain nutrient concentrations while year and tillage had small influences. Most stover nutrient concentrations were affected by the year $\mathrm{x}$ tillage, year $\mathrm{x}$ cropping system with soil amendment, and tillage $\mathrm{x}$ cropping system with soil amendment interactions, but differences were small. Results also indicated that nutrient concentrations of sorghum grain were adequate to meet human nutritional requirements for $\mathrm{N}, \mathrm{P}$, $\mathrm{Mg}, \mathrm{Zn}$ and $\mathrm{Fe}$, but deficient for $\mathrm{K}, \mathrm{Mn}$ and $\mathrm{Cu}$. Sorghum nutrient concentrations exceeded requirements for cattle feed for the stover yield levels produced this study, except for $\mathrm{Cu}$. Clearly, cattle fed sorghum stover requires $\mathrm{Cu}$ supplementation which could be obtained through management or cultivar selection. Management of sorghum grain and stover $\mathrm{K}, \mathrm{Mn}$ and $\mathrm{Cu}$ concentrations merit research. Nutrient concentrations of grain and stover should be included along with yields as parameters to evaluate sorghum management systems.

\section{Acknowledgements}

The McKnight Foundation, Institut de l'Environnement et de Recherches Agricoles (INERA), and the University of Lincoln-Nebraska are recognized for their financial and administrative support of this research. We acknowledge Dr Korodjouma OUATTARA, Mr. Bakary MAGANE and Mr. Augustin SOURWEIMA for the high-quality technical support provided during this research. 
Vol. 06, No. 03; 2021

ISSN: $2456-8643$

\section{REFERENCES}

Bidinger FR,Blümmel M, 2007. Determinants of ruminant nutritional quality of pearl millet (Pennisetum glaucum (1.) R. Br.) stover. I. Effects of managements alternatives on stover quality and productivity. Field Crops Research 103:119-128. https://doi.org/10.1016/j.fcr.2007.05.006.

Buerkert A, Haake C, Ruckwied M, Marschner H, 1998. Phosphorus application affects the nutritional quality of millet grain in the Sahel. Field Crops Research57:223-235). DOI: 10.1016/S0378-4290(97)00136-6.

Cox FR, Unruh L, 2000.Grain Sorghum, In SAAESD, Reference sufficiency ranges for plant analysis in the Southern Regio of the United States. Southern Coop Series Bulletin394:19-22. Raleigh, North Carolina, United States.

FAO, 2021. FAOSTAT. Online at http://www.fao.org/faostat/en/\#data/QC. Verified 25 Jan 2021.

Gadberry S, 2018. Beef Cattle Nutrition Series Part 3: Nutrient Requirement Tables. Univ. of Arkansas, Fayetteville, Arkansas, United States. p. 26.

Kruger J, Taylor JRN, Oelofse A, 2012. Effects of reducing phytate content in sorghum through genetic modification and fermentation in in vitro iron availability in whole grain porridges. Food Chemistry131 :220-224.DOI: 10.1016/j.foodchem.2011.08.063.

Kumar R, Mishra JS, Dwivedi SK, Kumar R, Rao KK, Samal SK, Choubey AK, Bhatt BP,2017. Nutrient uptake and content in sorghum cultivars (Sorghum bicolor L.) under summer environment. Indian Journal of Plant Physiology 22(3) :309-315.https://doi.org/10.1007/s40502017-0306-z.

Liboreiro Paiva C, Vieira Queiroz VA, Ferreira Simeone ML, Schaffert RE, de Oliveira AC, da Silva CS, 2017.Mineral content of sorghum genotypes and the influence of water stress. Food Chemistry 214:400-405.DOI: 10.1016/j.foodchem.2016.07.067.

Mabelebele M, Siwela M, Gous RM,Iji PA, 2015.Chemical composition and nutritive value of South African sorghum varieties as feed for broiler chickens. South African Journal of Animal Science 45(2): 206-213. Online at http://dx.doi.org/10.4314/dajas.v4512.12. Verified 24 Jan 2021. Pages?

Mason SC, Ouattara K, Taonda SJ-B, Palé S, Sohoro A,Kaboré D, 2015. Soil and cropping system research in semi-arid West Africa as related to the potential for conservation agriculture. International Journal of Agricultural Sustainability 13 :120-134. DOI: https://doi.org/10.1017/S0014479703001261.

Maw MJW, Houx III JH,Fritschi B, 2020. Nitrogen fertilizations of high biomass sorghum affects macro- and micronutrient accumulation and tissue concentrations. Industrial Crops and Products 156. Online at http://doi.org/10.1016/jindcrop.2020.112819. Verified 24 Jan 2021. 
Vol. 06, No. 03; 2021

ISSN: $2456-8643$

Miller RO, Kotuby-Amacher J, Rodriguez JB, 1997.Total Nitrogen in Botanical Materials Automated Combustion Method. Soil and Plant Analytical Methods, Version 4, pp. 106-107. Western States Laboratory Proficiency Testing Program. Soil Science Society of America, Madison, Wisconsin, United States.

National Academy of Science, 2019a. Dietary reference uptakes (DRIS): Recommended dietary allowances and adequate uptakes, total water and macronutrients. Appendix J Table d, Food and Nutrition Board, Nat. Acad. Sci., Washington, D.C., United States. Online at www.ncbi.nlm.gov/books/NBK545442.table.appj_tab/?report=objectonly.

National Academy of Science, 2019b. Dietary reference uptakes (DRIS): Recommended dietary allowances and adequate uptakes, elements. Appendix J Table c, Food and Nutrition Board, Nat. Acad. Sci., Washington, D.C., United States. Online atwww.ncbi.nlm.gov/books/NBK545442.table.appj_tab/?report=objectonly.

Palé S, Taonda SJ-B, Mason SC, Serme I, Sohoro A, Ouattara K, 2021. Pearl millet grain nutrient concentrations as influenced by cropping system, tillage methods and soil amendment. International Journal of Sciences 10 :1-8. DOI: 10.18483/ijSci.2436.

Palé S, Taonda SJ-B, Serme I, Ouattara K, Mason SC,Sohoro A, 2020. Sorghum and cowpea yields as influenced by tillage, soil amendment and cropping system in the Sudano-sahelian agroecological zone of Burkina Faso. Journal of Agricultural Science and Food Technology 6(1):19-27. DOI: 10.36630/jasft_20001.

SAS Institute, (2010). SAS/STAT ${ }^{\circledR}$ version 9.2. Cary, North Carolina, United States.

Taylor J, Taylor JRN, Kini F,2012. Cereal biofortification: strategies, challenges, and benefits. Cereal Foods World 57(4):165-169.

Van Duivenbooden N, 1992.Sustainability in terms of nutrient elements with special reference to West-Africa.Cabo-dlo Report 160. Wageningen, Netherlands.

Wolf A, Watson M, Wolf N, 1998. Method 5.4 Digestion and dissolution methods for P, K, Ca, $\mathrm{Mg}$ and trace elements, IN Peters, J (ed.). Recommended Methods of Manure Analysis. Pub. A3769, pp. 35-36. Univ. Wisconsin Coop. Ext. Service, Madison, Wisconsin, United States (2003).

World Bank, 2021. Population growth (annual \%) - Sub-Saharan Africa, Sub-Saharan Africa. Online at https://data.worldbank.org/indicator/SP.POP.Growth?locations=AG-ZF . Verified on 25 Jan, 2021.

Wortmann CS, Dicko MK, Maman N, Senkoro CJ, Tarfa BD, 2018. Fertilizer application effects on grain and storage root nutrient concentration. Agronomy Journal1 10:2619-2625. https://doi.org/10.2134/agronj2018.04.0274.

Wortmann CS, Kaizzi KC, Maman N, Cyamweshi A, Dicko M, Garba M, Milner M, Senkoro C, Tarfa B, Tettah F, Kibunja C, Munthali M, Nalivata P, Nkonde D, Nabahungu L, Ouattara 
K,Serme I, 2019. Diagnosis of crop secondary and micro-nutrient deficiencies in sub-Saharan Africa. Nutrient Cycling in Agroecosystems 113:127-140. https://doi.org/10.1007/s10705-01809968-7.

Youngquist JB, Carter DC, Clegg MD, 1990. Grain and forage yield and stover quality of sorghum and millet in low rainfall environments. Experimental Agriculture26:279-286. DOI: https://doi.org/10.1017/S0014479700018433. 